\title{
Evaluation of chemical composition, mineral, amino acid profile and fatty acid acid silage of Nile tilapia Oreochromis niloticus (Linnaeus) cultured in Indaiatuba - SP 1.
}

\author{
Avaliação da composição centesimal, mineral, perfil de aminoácidos e ácidos graxos da silagem \\ ácida de tilápia do Nilo Oreochromis niloticus (Linnaeus) cultivadas em Indaiatuba -SP ${ }^{1}$ \\ Ronaldo de Oliveira Sales ${ }^{2}$, Admar Costa de Oliveira ${ }^{3}$, \\ ${ }^{1}$ Parte da Tese de Doutorado do primeiro autor. \\ ${ }^{2}$ Universidade Federal do Ceará - DZ/CCA/UFC. \\ ${ }^{3}$ Universidade Estadual de Campinas/UNICAMP
}

\begin{abstract}
The research investigated the nutrient composition of the Nilo tilapia (Oreochromis niloticus (Linnaeus), acidic silage aiming at its utilization in substitution to fish flaour for animal nutrition. It was produced from "Nilo tilapia" autolysis in $3 \%(\mathrm{w} / \mathrm{w})$ formic acid by staring the minced fish in polyetilene container with a whole on the top to hit scape of gases, at $22-25^{\circ} \mathrm{C}$ for 90 days. Determination of humidity, protein, lipids, ask and specific minerals were performed following a complete randomized procedure. Varance Analysis did not show statistical diferences ( $>0,05)$ among samples for centesimal composition and minerals. A higher magnitude of amino acids de composition was fecund in the silages stored for 90 days. Ninety eight percent ( $98 \%$ ) of the 22 fatty scids determined contained 10 to 22 carbon atoms, and 22 of them acounted for less then $1 \%$ concentration in the silages.
\end{abstract}

Keywords: acid silage, fish removal

RESUMO: A pesquisa avaliou a composição da silagem ácida da despesca da tilápia do Nilo (Oreochromis (Oreochromis) niloticus (Linnaeus), visando sua utilização em substituição à farinha de peixe na alimentação animal. Foi produzida a partir da despesca da tilápia do Nilo em 3\% (p/p) de ácido fórmico, armazenada em temperatura ambiente 22 a $25^{\circ} \mathrm{C}$ por 90 dias em baldes de polietileno com um orifício, por onde os gases saiam. Foram realizadas análises para determinação da umidade, proteína, lipídios e cinza e minerais. O perfil de aminoácidos foi determinado em auto-analisador após hidrólise, à exceção do triptofano, seguindo-se o delineamento inteiramente casualizado. A análise de variância não mostrou diferença $(p>0,05)$ para composição centesimal e mineral entre as amostras analisadas. Constatou-se que a magnitude da decomposição dos aminoácidos, foi maior na silagem armazenada durante 90 dias. Noventa e oito dos 22 ácidos graxos (AG) encontrados na silagem continham de 10 a 22 carbonos, sendo que 12 desses AG estavam em concentrações inferiores a $1 \%$.

Palavras-chave: silagem ácida, despesca de pescado.

Autor para correspondência: E-mail: *ronaldo.sales@ufc.br

Recebido em 03/03/2015; Aceito em 13/09/2015

http://dx.doi.org/10.5935/1981-2965.20150033 


\section{INTRODUCTION}

Transforming fish waste into a product that can be used as an ingredient for animal feed is a method used to minimize environmental problems caused by the large amounts of fish waste (RISTIC et al., 2002).

An alternative with great potential is using the loss of catch and fish processing waste (which can be up to $60 \%$ of the total produced or caught) to create fish silage. That is a valuable product with a high biological value, which makes it an excellent alternative because it adds value to the solid fish waste (ACCARIN \& CAMARGO, 2005).

The nutritional value of the fish silage lays in its high protein digestibility. That is because the protein is already quite hydrolyzed, and there are high concentrations of lysines and tryptophan, among other essential amino acids. After the bioconversion, the product becomes a source of high quality autolysed proteins, which can be used to feed animals and to produce new food, becoming a source of free amino acids and high quality peptides. This is difficult to obtain through other technological processes (BORGHESI et al.,
2008). It can also be useful as an organic fertilizer due to its rich nutrients in the scales, skin, bones, collagen, blood, fat, swim bladders, gonads, eyes, brains, livers, digestive enzymes and carotenoids (BEERLI et al. 2004).

The goal of this study is to evaluate the chemical and mineral composition, amino acids profile and fatty acids of the acid silage of the Nile tilapia (Oreochromis niloticus (Linnaeus) cultured in Indaiatuba $\mathrm{SP}$, as an alternative ingredient for animal feed.

\section{MATERIAL AND METHODS}

The raw material to obtain the chemical silage of fish was Nile tilapia (Oreochromis niloticus (Linnaeus), harvested from commercial culturing in Indaiatuba, São Paulo. It was fragmented using a grinder, which is an electrical device, model ML-4,0/Weg-uline, totalling $5 \mathrm{~kg}$ in each lot. After, it was homogenized, weighed and evenly distributed in hard plastic containers. Formic acid was added in a $3 \%(\mathrm{w} / \mathrm{w})$ relation of the volume of the acid solution to the mass of the fish waste (SEIBEL \& SOUZA-SOARES, 2003). 
The material was shaken frequently in order to spread the enzymes, thus accelerating the liquefaction rate $(\mathrm{MACH}$ DIEP \& NORTVEDT, 2009) and producing the chemical silage of the tilapia. The $\mathrm{pH}$ was controlled daily in order for the material to stay close to 4.0 .
Following this, the material went through a decanting process for 15-20 days to separate the integral and partially defatted parts. The silage remained at room temperature $\left(27^{\circ} \mathrm{C} \pm 3^{\circ} \mathrm{C}\right)$ for 72 hours, when it went through its chemical composition analysis, as shown in Figure 1.

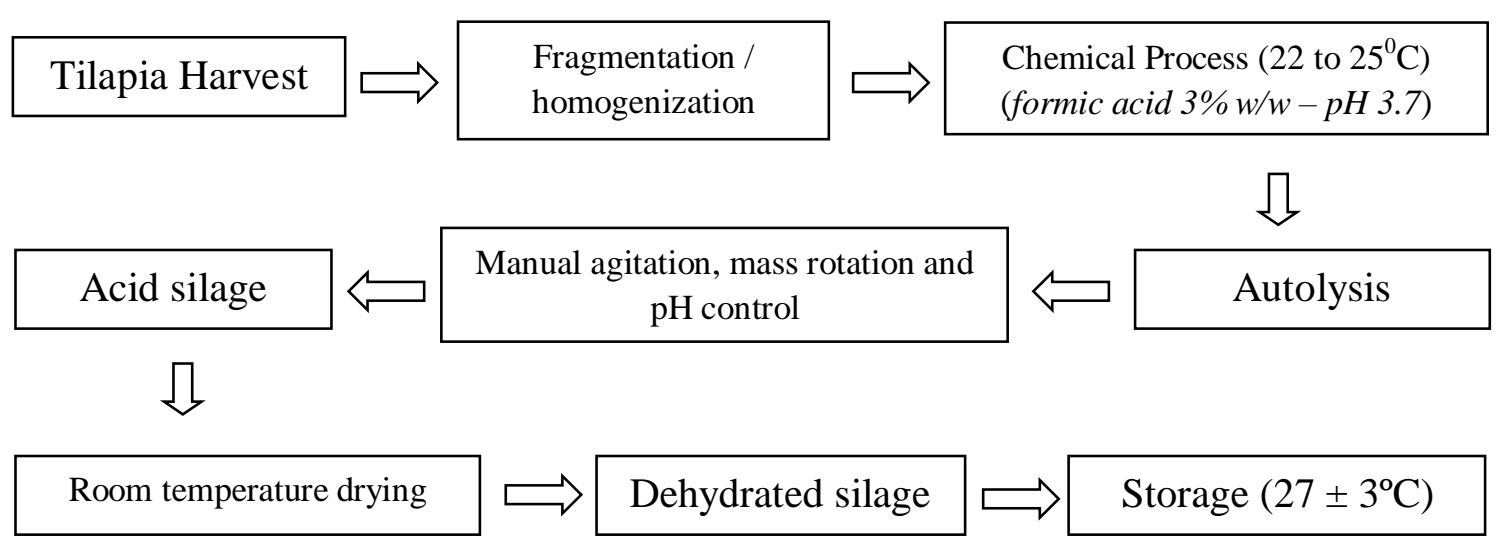

Figure 1. Flowchart of the processing for the production of acid silage of Nile tilapia harvest.

Analyses were performed to determine the chemical composition for the chemical silage of the tilapia. All the analyses were triplicated and done according to A.O.A.C. (2000). The humidity was measured by the gravimetric method in an oven at $105^{\circ} \mathrm{C}$ until constant weight was achieved. The protein was measured through the Micro-Kjeldahl method, with digestion done in a block digester, and after, a distillation in the attached distiller and titration with sulphuric acid $0.02 \mathrm{~N}$. The lipid fraction was obtained by the extractor Soxhlet, using petroleum ether as a solvent, followed by heating in the oven until the solvent evaporated completely. The ash level was measured through the gravimetric method in muffle at $550^{\circ} \mathrm{C}$ and incineration of the organic matter using a Bunsen burner. The levels of mineral, calcium, magnesium and iron were determined by atomic absorption spectrophotometry, and the 
phosphorus level was determined calorimetrically. The amino acids were measured after the acid and basic digestion and separated by chromatography of ion exchange (HPLC). The samples were analyzed by liquid chromatography in ion exchange resin columns and post-column derivation with ninhydrin in auto-analyzer. In order to quantify the amino acids, the samples were hydrolyzed with HCL $6 \mathrm{~N}$ for 22 hours at $110^{\circ} \mathrm{C}$ (MOORE \& STEIN, 1963). Tryptophan was measured after the enzyme hydrolysis with Pronase at $40^{\circ} \mathrm{C}$ for 24 hours, following a colorimetric reaction with 4 dimethyl-amino-benzaldehyde (DAB) in sulphuric acid 21.2 $\mathrm{N}$ and measuring at $590 \mathrm{~nm}$, calculated based on a standard curve, according to SPIES (1967).

The chemical score was performed according to SGARBIERI (1987), through the relation between the level of each essential amino acid with the corresponding amino acid level from a FAO standard protein (1985). The fatty acids went through saponification and esterification to obtain methyl-esters (HARTMAN \& LAGO, 1973). Data was analyzed according to a completely randomized experimental design (BARBOSA \& MALDONADO, 2010). The variance analysis was carried out, and the Tukey test at $5 \%$ probability was used to compare averages.

\section{RESULTS AND DISCUSSION}

There was no statistical difference $(\mathrm{P}>0,05)$ in the chemical composition among the analyzed lots of Nile tilapia that were used for the preparation of the fish acid silage. The average values were $76.62 \%$, $17.7 \%, 3.57 \%$ and $2.33 \%$ respectively for humidity, protein, lipids and ashes (Table 1). This data is compatible with that reported by SEIBEL \& SOUZA-SOARES (2003), who, by analyzing the composition of the hybrid Tilapia nilotica with Tilapia hornorum, obtained humidity levels from $74.32 \%$ to $75.63 \%$, protein levels from $17.52 \%$ to $17.62 \%$, ash levels from $1.73 \%$ to $2.32 \%$ and lipid levels from $3.75 \%$ to $7.48 \%$. The largest variation coefficient $(\mathrm{CV} \%)$ occurred in the ash content with $26.29 \%$, followed by the level of lipids with $9.20 \%$, protein with $2.24 \%$ and lastly humidity with $1.30 \%$.

SALES (1995) obtained similar results. While working with different species of Nile tilapia, no statistical differences were observed $(\mathrm{P}>0.05)$ among the analyzed samples. There were larger variations in ash levels $(0.7-4.2 \%)$, and the 
smallest in the humidity and protein levels, in which almost all species have similar values, the tilapia being a lean fish (3.25 to $6.26 \%$ ) with a high protein level. According to ESPE \& LIED (1999), the Nile tilapia's chemical composition varies according to the species, and even within the same species. That depends on the time of the year, the type of feeding, the gonad maturation and the gender. There can be variations within the same fish, depending on the part that is analyzed.
There was no statistical difference ( $>0.05)$ among the analyzed samples of the four lots of acid silage of Nile tilapia (Oreochomis nilóticus (Linnaeus), (whole fish with viscera, skin and scales) from Indaiatuba, São Paulo, during the harvesting phase (Table 2). The largest variation was in the lipid level with a coefficient of variation (CV) of $14.19 \%$, followed in smaller proportion by the ash level with $1.91 \%$, protein with $0.79 \%$ and humidity with $0.42 \%$.

Table 1. Chemical composition Nile tilapia (Oreochromis nilóticus (Linnaeus), (whole fish with viscera, skin and scales) from Indaiatuba, São Paulo, during the harvesting phase.

\begin{tabular}{lcccc}
\hline \multicolumn{1}{c}{ Sample } & Humidity $\%$ & Protein $\%$ & Lipids $\%$ & Ashes \% \\
\hline Lot 1 & 76.64 at \pm 1.50 & 17.07 at \pm 0.53 & 3.56 at \pm 0.00 & 2.33 at \pm 1.09 \\
Lot 2 & 76.63 at \pm 0.71 & 17.08 at \pm 0.45 & 3.59 at \pm 0.14 & 2.34 at \pm 0.50 \\
Lot 3 & 76.62 at \pm 0.48 & 17.07 at \pm 0.31 & 3.58 at \pm 0.05 & 2.35 at \pm 0.19 \\
Lot 4 & 76.61 at \pm 1.01 & 17.08 at \pm 0.09 & 3.55 at \pm 0.64 & 2.33 at \pm 0.19 \\
\hline F & $0.00^{\mathrm{NS}}$ & $0.00^{\mathrm{NS}}$ & $0.01^{\mathrm{NS}}$ & $0.00^{\mathrm{NS}}$ \\
CV $(\%)$ & 1.30 & 2.24 & 9.20 & 26.29 \\
DMS & 2.6162 & 1.0022 & 0.8590 & 1.6067 \\
\hline Average & 76.62 & 17.07 & 3.57 & 2.33 \\
\hline
\end{tabular}

Average values and standard deviations of 3 measures. Average values on the same column marked with the same letters do not present statistical differences according to the Turkey test at a 5\% probability.

Similar results were reported by in the chemical composition the same raw BUENO (2006). While working with acid material that originated it, thus silage of tilapia filleting residues, they found demonstrating the homogeneity of the final 
product, which was supported by other authors ESPE \& LIED (1999). In this way, the $3 \%$ level of formic acid at $98 \%$ in relation to the weight of the ground fish, as generally recommended in the literature SEIBEL \& SOUZA-SOARES (2003), was deemed satisfactory, not altering the chemical composition data and staying constant throughout the 90-day storage period at a temperature of $27 \pm 3^{\circ} \mathrm{C}$. FERRAZ DE ARRUDA (2004), working with fish waste, recommends mixing formic and propionic acid in a 1:1 proportion, and adding 1.5 at $3 \%(\mathrm{v} / \mathrm{p})$ in relation to the mass, with the goal of obtaining a silage that is stable and that does not contain pathogenic microorganisms.

BORGHESI (2007), while analyzing the chemical composition and the nutritional quality of the acid (AS), biological (BS) and enzymatic silages (ES), done from Nile tilapia (Oreochromis niloticus) waste, found the following values (based on dry material): 54.25; 53.00 and $54.50 \mathrm{~g} / 100 \mathrm{~g}$ for crude protein; 12.45; 12.25 and $12.17 \mathrm{~g} / 100 \mathrm{~g}$ for lipids; 8.03; 7.33 and $8.58 \mathrm{~g} / 100 \mathrm{~g}$ for calcium and 4.71;
2.86 and $4.85 \mathrm{~g} / 100 \mathrm{~g}$ for phosphorus, respectively for $\mathrm{AS}, \mathrm{BS}$ and $\mathrm{ES}$. The three types of silage had all the of essential of amino acids (EAA). Among the EAA, in general, leucine $(3.50 ; 2.41$ and $3.31 \mathrm{~g} / 100 \mathrm{~g}$ for $\mathrm{AS}, \mathrm{BS}$ and $\mathrm{ES}$, respectively) and lysine (3.33; 2.41 and $3.22 \mathrm{~g} / 100 \mathrm{~g}$ for $\mathrm{AS}, \mathrm{BS}$ and ES, respectively) appeared in higher concentration in the silages. Berenz (1994), preparing biological silages with 5\% yogurt and 10\% sugar cane molasses, obtained a product with $63.32 \%$ humidity and $18.46 \%$ crude protein (humid base).

On Table 3, it can be noted that the lipids levels decreased from $3.26 \%$ to $0.48 \%$ after the oil removal process through decantation, which lasted 15 to 20 days during the storage process. According to some authors, MEURER et al., 2002, lipids are immediate sources of energy and essential fatty acids for the majority of fish species, and are present in large amounts in planktonic organisms. WANG et al. (2005) correlated the larger concentration of body lipid with the feeding type, gonad maturation degree and gender. 
Sales et al., / Brazilian Journal of Hygiene and Animal Sanity (v.9, n.3) (2015) 348-363

Table 2. Chemical composition of the integral acid silage of Nile tilapia (Oreochomis (Oreochromis) nilóticus (Linnaeus), (whole fish with viscera, skin and scales) from Indaiatuba, São Paulo, during the harvesting phase.

\begin{tabular}{lcccc}
\hline \multicolumn{1}{c}{ Sample } & Humidity \% & Protein \% & Lipids \% & Ashes \% \\
\hline Lot 1 & 77.24 at \pm 0.11 & 16.30 at \pm 0.07 & 3.28 at \pm 0.50 & 3.19 at \pm 0.01 \\
Lot 2 & 77.25 at \pm 0.24 & 16.31 at \pm 0.21 & 3.27 at \pm 0.36 & 3.18 at \pm 0.01 \\
Lot 3 & 77.26 at \pm 0.29 & 16.32 at \pm 0.05 & 3.26 at \pm 0.05 & 3.17 at \pm 0.08 \\
Lot 4 & 7.27 at \pm 0.52 & 16.31 at \pm 0.12 & 3.25 at \pm 0.69 & 3.16 at \pm 0.09 \\
\hline F & $0.00^{\mathrm{NS}}$ & $0.01^{\mathrm{NS}}$ & $0.00^{\mathrm{NS}}$ & $0.14^{\mathrm{NS}}$ \\
CV $(\%)$ & 0.42 & 0.79 & 14.19 & 1.91 \\
DMS & 0.8515 & 0.3356 & 1.2111 & 0.1585 \\
\hline Average & 77.25 & 16.31 & 3.26 & 3.17 \\
\hline
\end{tabular}

Average values and standard deviations of 3 measures. Average values on the same column marked with the same letters do not present statistical differences according to the Turkey test at a 5\% probability.

Table 3. Chemical composition of the defatted acid silage of Nile tilapia (Oreochromis niloticus (Linnaeus), (whole fish with viscera, skin and scales) from Indaiatuba, São Paulo, during the harvesting phase.

\begin{tabular}{lcccc}
\hline \multicolumn{1}{c}{ Sample } & Humidity \% & Protein \% & Lipids \% & Ashes \% \\
\hline Lot 1 & 77.64 at \pm 0.11 & 17.25 at \pm 0.07 & 0.48 at \pm 0.20 & 3.63 at \pm 0.01 \\
Lot 2 & 77.69 at \pm 0.24 & 17.24 at \pm 0.21 & 0.49 at \pm 0.19 & 3.64 at \pm 0.01 \\
Lot 3 & 77.66 at \pm 0.29 & 17.25 at \pm 0.05 & 0.48 at \pm 0.17 & 3.63 at \pm 0.08 \\
Lot 4 & 77.43 at \pm 0.52 & 17.21 at \pm 0.12 & 0.48 at \pm 0.17 & 3.62 at \pm 0.09 \\
\hline F & $0.40^{\mathrm{NS}}$ & $0.07^{\mathrm{NS}}$ & $0.00^{\mathrm{NS}}$ & $0.05^{\mathrm{NS}}$ \\
CV $(\%)$ & 0.42 & 0.74 & 37.92 & 1.67 \\
DMS & 0.8515 & 0.3356 & 0.4784 & 0.1585 \\
\hline Average & 77.66 & 17.23 & 0.48 & 3.63 \\
\hline
\end{tabular}

Average values and standard deviations of 3 measures. Average values on the same column marked with the same letters do not present statistical differences according to the Turkey test at a 5\% probability. 
Table 4 illustrates the results of the composition in $\mathrm{Ca}, \mathrm{P}, \mathrm{Mg}$ and $\mathrm{Fe}$ in the acid silage of Nile tilapia. It should be noted that there were no statistical differences $(\mathrm{P}>$ 0.05) among the 4 analyzed lots, with an average of $1.43 \mathrm{mg} / 100 \mathrm{~g}, 0.97 \mathrm{mg} / 100 \mathrm{~g}$, $0.61 \mathrm{mg} / 100 \mathrm{~g}$ and $0.07 \mathrm{mg} / 100 \mathrm{~g}$,

Table 4. Composition in $\mathrm{Ca}, \mathrm{P}, \mathrm{Mg}$ and $\mathrm{Fe}$ of the acid silage ${ }^{1}$ of the Nile tilapia (Oreochromis nilóticus (Linnaeus) (whole fish with viscera, skin and scales) from Indaiatuba, São Paulo, during the harvesting phase.

\begin{tabular}{lcccc}
\hline \multicolumn{1}{c}{ Sample } & $\begin{array}{c}\text { Calcium } \\
\mathbf{m g} / \mathbf{1 0 0 g}\end{array}$ & $\begin{array}{c}\text { Phosphorus } \\
\mathbf{m g} / \mathbf{1 0 0 g}\end{array}$ & $\begin{array}{c}\text { Magnesium } \\
\mathbf{m g} / \mathbf{1 0 0 g}\end{array}$ & $\begin{array}{c}\text { Iron } \\
\mathbf{~ m g} / \mathbf{1 0 0 g}\end{array}$ \\
\hline Lot 1 & 1.41 at \pm 0.01 & 0.96 at \pm 0.01 & 0.60 at \pm 0.01 & 0.08 at \pm 5.77 \\
Lot 2 & 1.42 at \pm 0.01 & 0.97 at \pm 0.01 & 0.61 at \pm 0.01 & 0.05 at \pm 0.01 \\
Lot 3 & 1.42 at \pm 0.01 & 0.98 at \pm 0.01 & 0.62 at \pm 0.01 & 0.07 at \pm 0.01 \\
Lot 4 & 1.43 at \pm 0.01 & 0.97 at \pm 0.01 & 0.62 at \pm 0.01 & 0.08 at \pm 0.01 \\
\hline F & $2.00^{\mathrm{NS}}$ & $2.00^{\mathrm{NS}}$ & $2.75^{\mathrm{NS}}$ & $2.00^{\mathrm{NS}}$ \\
CV $(\%)$ & 0.70 & 1.03 & 1.63 & 24.74 \\
DMS & 0.0261 & 0.0261 & 0.0261 & 0.0453 \\
\hline Average & 1.42 & 0.97 & 0.61 & 0.07 \\
\hline
\end{tabular}

Average values and standard deviations of 3 measures. Average values on the same column marked with the same letters do not present statistical differences according to the Turkey test at a 5\% probability.

Similar results were obtained by BUENO (2006), who by studying the acid silage of fish, reported that calcium presented values between 0.7 to $1.65 \mathrm{mg} / 100$ $\mathrm{g}$ of silage, phosphorus, with values between respectively, calcium, phosphorus, magnesium and iron. The largest variation was in the iron level, with a coefficient of variation $(\mathrm{CV})$ of $24.74 \%$, followed by the magnesium level, with $1.63 \%$, phosphorus, with $1.03 \%$, and calcium with $0.70 \%$. 
OLIVEIRA RODRIGUES et al. (2007), after analyzing the acid silage of Nile tilapia, concluded that manganese is present in the acid silage of fish in the 0.5 to $0.7 \mathrm{mg} / 100 \mathrm{~g}$ levels of the silage.

In Table 5, the essential amino acids profile ( $\mathrm{g} / 16 \mathrm{~g}$ of $\mathrm{N})$ can be compared in the new silage, old silage, soybean meal, casein and corn, as well as the values of the chemical score to obtain the quality of the protein sources, obtained in relation to the reference theoretical pattern of the NATIONAL ACADEMY OF SCIENCES, 1980.

In table 5 , in can be noted that by comparing the tilapia acid silages (new and old) with soybean meal, casein and corn, the latter presents lower quantities in relation to each amino acid, that is, particularly in relation to sulphurized compounds such as methionine. There were also very low levels of aspartic and glutamic acid, also presenting many similarities with fish meal when made from the same raw material. However, it must be highlighted that these products are not produced from the same raw material, which demonstrates that the silages offer an optimal response in terms of amino acid profile, growth rate and feed efficiency (SALES, 1995).

The chemical score (CS) indicated a relation between the reference or standard protein, the order of the limiting amino acids in the protein being studied, with the value found for the most limiting amino acid being an estimate of the biological or nutritional value of the protein being studied (SGARBIERI, 1987). The standard protein was defined by the NATIONAL RESEARCH COUNCIL (1980) as having the following concentrations for EAAs $(\mathrm{g} / 100 \mathrm{gN})$ (see table 5).

ESPE \& LIED (1999) reported that the silage produced by manual processing presents high values of essential amino acids such as lysine $(5.54 \mathrm{~g} / \mathrm{kg})$, histidine $(5.33$ $\mathrm{g} / \mathrm{kg}$ ) and glutamic acid (6.04 g/kg), making it an excellent alternative because it adds value to organic waste in solid fish residues.

It was noted that the amino acid decomposition was larger in the silage stored for 90 days than in the samples taken during the first 30 days in which there was a smaller quantity of decomposed products, particularly of essential amino acids like leucine, isoleucine, lysine and tryptophan, significantly affecting the weight gain in 
animals in relation to the silages stored for long periods of time (SALES, 1995).

Table 5. Amino acids profile ( $\mathrm{g} / 16 \mathrm{~g} \mathrm{~N}$ ) and chemical score of the protein sources used for elaborating diets, which was measured by ion exchange.

\begin{tabular}{lcccccc}
\hline \multicolumn{1}{c}{ Amino acid } & New silage & Old silage & Soybean meal & Casein & Corn & Pattern \\
\hline Isoleucine & 5.64 & 3.80 & 1.81 & 5.4 & 2.5 & 4.2 \\
Leucine & 9.27 & 6.00 & 3.69 & 10.2 & 10.3 & 7.0 \\
Lysine & 9.90 & 6.80 & 2.65 & 7.8 & 2.2 & 5.1 \\
Methionine & 3.05 & 2.70 & 0.64 & 2.8 & 1.9 & - \\
1/2 Cystine & 1.22 & 0.98 & - & 0.2 & - & - \\
Total sulphurized & 4.27 & 3.90 & 0.64 & 3.0 & 1.9 & 2.6 \\
Tyrosine & 3.20 & 3.12 & - & 6.1 & - & - \\
Phenylalanine & 4.36 & 4.10 & 2.11 & 5.6 & 3.6 & - \\
Total aromatics & 7.56 & 7.22 & 2.11 & 11.7 & 3.6 & 7.3 \\
Threonine & 4.35 & 3.90 & 1.80 & 4.9 & 2.9 & 3.5 \\
Valine & 5.25 & 5.12 & 2.05 & 6.9 & 3.9 & 4.8 \\
Serine & 3.80 & 3.60 & 2.42 & 6.8 & 3.7 & - \\
Alanine & 8.10 & 4.23 & 2.12 & 3.2 & 6.3 & - \\
Tryptophan & 1.06 & 0.60 & - & - & - & 1.1 \\
Histidine & 2.20 & 2.10 & - & 2.9 & - & 1.7 \\
Arginine & 8.35 & 7.10 & 3.17 & 4.1 & 3.2 & - \\
Glutamic Acid & 18.27 & 12.30 & 8.82 & 27.4 & 17.2 & - \\
Aspartic Acid & 12.30 & 7.00 & 5.13 & 8.6 & 5.4 & 7.8 \\
Glycine & 8.12 & 6.05 & 1.98 & 1.9 & 3.0 & - \\
Proline & 4.25 & 3.90 & 2.33 & 10.0 & 7.2 & \\
\hline Chemical Score & 96.30 & 54.5 & 24.6 & 110.25 & 43.1 & \\
\hline
\end{tabular}

${ }^{\mathrm{T}}$ Theoretical pattern (National Academy of Sciences, 1980).

Note: The tryptophan content was measured using the Spies method (1967). 
Covalent bonds between oxidized products and proteins can destroy amino acids such as tryptophan, oxidize methionine and bind lysine to other compounds, making these amino acids unavailable (NELSON \& COX, 2000). A likely explanation for the reduction of the nutritional value could be the fact that the free amino acids are quickly deviated from the protein synthesis and enter the catabolic route, thus the free amino acids are more available to be used as a source of energy than the intact proteins (VIDOTTI, 2001; VIDOTTI et al., 2003). In the presence of hydroxyls coming from sugar, free amino acids have a Maillard reaction, resulting in a decrease of the nutritional value of the silage (FAGBENRO \& JAUNCEY, 1998).

Table 6 shows the composition of the fatty acids of the oil extracted from the acid silage of Nile tilapia, stored at room temperature. In this study, approximately 98\% of the fatty acids (FA) in the silage were identified, corresponding to 22 different FAs, ranging from 10 to 22 carbon atoms; 12 of these FAs were found in concentrations lower than $1 \%$. Oleic acid (18:1) was the FA found in larger quantity in the acid silage of Nile tilapia, supporting the results presented in the literature (LEGENDRE \& KERDCHUEN, 1995).

It was also noted that the fatty acids 16:0, 16:1, 16:2, 17:0, 18:1, 18:2, 18:3 (n 3) and 20:5 (n - 3), which together amount to $85.19 \%$ of the fatty acids in the Nile tilapia silage, are responsible for a large part of the alterations in food, which can produce undesirable effects such as rancidity, discoloration and direct loss of nutrients. These create the possibility of damaging the intestinal walls of animals, decreasing weight gain and feed conversion, as well as the ingestion of hydroperoxides, which are initial products of lipid oxidation, a process that is important in terms of nutrition.

FERRAZ DE ARRUDA (2004), while evaluating the profile of fatty acids of Nile tilapia silages, found a predominance of unsaturated fatty acids. The oleic acid (C 18:1) had the largest amounts $(28.60 \mathrm{~g} / 100$ of oil). There were also traces of eicosapentaenoic fatty acids (EPA - C20:5) and docosahexaenoic (DHA - C22:6). ESPINDOLA FILHO (1999), while studying acid silage with 60 days of storage produced from different raw materials, 
obtained values of $1.1 \mathrm{~g} / 100 \mathrm{~g}$ of oil for EPA and $1.1 \mathrm{~g} / 100 \mathrm{~g}$ of oil for DHA. Approaching another form of using fish silage in feeding for aquaculture, MAIA et al. (1998) characterized the lipidic fraction of tilapia residue silage, affirming that the oil obtained from the silage process is a source of high quality and low cost unsaturated lipids. However, the fatty acids profile tends to vary according to the raw material used in elaborating the silage.

Table 6. Composition of fatty acids (\%) in the Nile tilapia acid silage.

\begin{tabular}{cccc}
\hline Fatty acid & $\%$ & Fatty acid & $\%$ \\
\hline $10: 0$ & $0.13 \pm 0.05$ & $18: 1$ & $22.14 \pm 0.56$ \\
$12: 0$ & $0.07 \pm 0.05$ & $18: 2(\mathrm{n}-6)$ & $8.45 \pm 1.30$ \\
$13: 0$ & $0.14 \pm 0.16$ & $18: 3(\mathrm{n}-3)$ & $4.53 \pm 0.90$ \\
$14: 0$ & $4.44 \pm 0.44$ & $19: 0$ & $0.68 \pm 0.39$ \\
$14: 1$ & $0.34 \pm 0.03$ & $20: 0$ & $0.51 \pm 0.25$ \\
$14: 2$ & $0.84 \pm 0.09$ & $20: 1$ & $1.50 \pm 0.39$ \\
$15: 0$ & $0.87 \pm 0.20$ & $20: 2$ & $0.24 \pm 0.01$ \\
$16: 0$ & $20.70 \pm 0.03$ & $20: 3(\mathrm{n}-3)$ & $0.14 \pm 0.14$ \\
$16: 1$ & $12.91 \pm 0.20$ & $20: 4(\mathrm{n}-6)$ & $1.46 \pm 0.49$ \\
$16: 2$ & $7.97 \pm 1.91$ & $20: 5(\mathrm{n}-3)$ & $3.69 \pm 0.37$ \\
$17: 0$ & $3.27 \pm 0.67$ & $22: 1$ & $1.53 \pm 0.13$
\end{tabular}

(*) Each value represents the average and the standard deviation of the analyzed samples.

\section{CONCLUSIONS}

The results obtained demonstrate the possibility of using acid silage of Nile tilapia (Oreochromis niloticus) harvesting as a protein-rich ingredient for well-balanced animal feed as a partial substitute to fishmeal. 
Sales et al., / Brazilian Journal of Hygiene and Animal Sanity (v.9, n.3) (2015) 348-363

\section{REFERENCES}

ACCARIN, A.E.; CAMARGO, A.F.M. Characterization and evaluation of the impact of feed management on the effluents of Nile tilapia (Oreochromis niloticus) culture. Brazilian Archives of Biology and Technology, v.48, n. 4, p.81-90, 2005.

AOAC. ASSOCIATION OF OFFICIAL ANALYTICAL CHEMISTS. HORWITZ, W. (Ed). Official methods of analysis of Official Analytical Chemists. 17.ed. Arlington, Virginia, USA, 2000. V. 1 e V 2. BARBOSA, J. C.; MALDONADO JR, W.; AgroEstat - Sistema para Análises Estatísticas de Ensaios Agronômicos, Versão 1.0, 2010.

BEERLI, E.L.; BEERLI, K.M.C.; LOGATO, P.V.R. Silagem ácida de resíduos de truta (Oncorhynchus mykiss), com utilização de ácido muriático. Ciência e Agrotecnologia, v.28, n.1, p. 195-198, 2004.

BORGHESI, R. et al. A silagem de pescado na alimentação de organismos aquáticos. Boletim do CEPPA, Curitiba, v. 25, n.2, p. 329 - 339 jul/dez. 2007.

BORGHESI, R. et al. Apparent digestibility coefficient of protein and amino acids of acid, biological and enzymatic silage for
Nile tilapia (Oreochromis niloticus). Aquaculture Nutrition v. 14, n. 3, p. 242248, 2008.

BOSCOLO W.R. et al. Desempenho e características de carcaça de tilápias do Nilo (Oreochromis niloticus L.) alimentadas com rações contendo diferentes níveis de gordura. Acta Scientiarum Animal Sciences, v.26, n.5, p.443-447, 2004.

BUENO, J.R. Silagem ácida de resíduos da filetagem de tilápia em dietas de alevinos de piauçu Leporinus macrocephalus. 2006. 45f. Dissertação (Mestrado em Aqüicultura) - Curso de pósgraduação em Aqüicultura, Universidade Estadual Paulista.

CARVALHO, G.G.P. et al. Silagem de resíduo de peixe em dietas para alevinos de tilápia-do-nilo. Revista Brasileira de Zootecnia, v.35, n.1, p. 126-130, 2006.

ESPE, M.; LIED, E. Fish silage prepared from different cooked and uncooked raw materials: Chemical changes during storage at different temperatures. Journal of the Science Food and Agriculture, v. 79, n. 2, p. 327-332, 1999.

ESPIDOLA FILHO, A. Aproveitamento do residuo sólido de peixe, camarào e bivalvos como ingrediente de ração para 
aquicultura. São Paulo, 1999. 224f. Tese (Doutorado em saneamento ambiental). (Universidade de Mackenzie.

FAGBENRO, O; JAUNCEY, K. Physical ad nutritional properties of moist fermented fish silage pellets as a protein supplement for tilapia (Oreochomis niloticus). Animal Feed Science Technology, v. 71, n. 3, p.1118,1998 .

FAO/WHO/UNU expert consultation. Energy and Protein requirements FAO/WHO nutrition meetings. Geneva: Food and Agriculture Organization/World Health Organization, 1985. Report series 724.

FERRAZ DE ARRUDA, L. Aproveitamento do resíduo do beneficiamento da tilápia do Nilo (Oreochromis niloticus) para obtenção de silagem e óleo como subprodutos. Piracicaba, 2004. 78 f. Dissertação (Mestrado em Ciência e Tecnologia de Alimentos), Departamento de Agroindústria, Alimentos e Nutrição, Universidade de São Paulo.

HARTMAN, L.; LAGO, R.C.A. Rapid preparation of fatty acid methyl esters from lipids. Laboratory Practice. v. 22, n. 4, p. 475-476, 1973.
LEGENDRE, M.; KERDCHUEN, N. Larval rearing of an African Catfish (Heterobranchus longifilis Teleostei, Claridae): effect of dietary lipids on growth survival and fatty acid composition of fry. Aquatic Living Resources, v.8, n.3, p.355363, 1995.

MACH DIEP, T.N.; NORTVEDT, R. Chemical and nutritional quality of silage made from raw or cooked lizard fish (Saurida undosquamis) and blue crab (Portunus pelagicus). Journal of the Science of Food and Agriculture. v. 89, n. 15, p. 2519-2526, 2009.

MAIA, W. et al. Caracterização da fração lipídica de silagem de resíduos de tilápia para utilização em rações para a aqüicultura. In: SIMPÓSIO BRASILEIRO DE AQUICULTURA, 10., Recife, 1998. Anais... Recife: Persona, 1998, v. 2, p.5564.

MOORE, I; STEIN, W.H. Chromatographic determination of amino acids by use of automatic recording equipaments. Methods in Emzimology, v.6, p.919-931,1963.

NATIONAL ACADEMY OF SCIENCES. National Research Council. Institute of Laboratory Animal Resources. ILAR. Laboratory Animal Management: Rodents. 
Separata do ILAR News, Washington, v. 20, n. 3, p.11-15, 1980.

\section{NATIONAL RESEARCH COUNCIL.} Nutrient requeriments of laboratory animals. 2. ed. v. $10 \mathrm{NCR}$, Washington D.C., 1988.

NELSON, D.L.; COX, M.M. Lehninger principles of biochemistry. New York: Worth Publication, 2000, 145p.

OLIVEIRA RODRIGUES, A.C. et al. Efeito da inclusão de silagem ácida de resíduos de pescado sobre a digestibilidade de dietas para ovinos. Revista Brasileira de Nutrição Animal. v.1, n. 2, p. 28 - 33, 2007.

RISTIC, M.D. et al. Liquid protein feedstuffs from freshwater fish by-products as a component of animal feed. Romanian Biotechnological Letters, v. 7, n. 3, p. 729736, 2002.

SALES, R.O. Processamento, caracterização química e avaliação nutricional da silagem da despesca da tilápia do Nilo (Oreochromis niloticus) em dietas experimentais com ratos, Campinas, 1995. 174p. Tese (Doutorado em Engenharia de Alimentos) (Universidade Estadual de Campinas).
SALES, J.; BRITZ, P.J. Apparent and true availability of amino acids from common feed ingredients for South African abalone (Haliotis midae L.). Aquaculture Nutrition, v.9, p. 55-64, 2003.

SEIBEL, N.F.; SOUZA-SOARES, L.A. Produção de silagem química com resíduo de pescado marinho. Brazilian Journal of Food Technology, v.6, n.2, p.333-337, 2003.

SGARBIERI, V.C. Alimentação e nutrição: fator de saúde e desenvolvimento. 2 ed. Campinas: UNICAMP, 1987. 387p.

SPACKMANN, D.H. et al. Automatic recording apparatus for use in the cromatography of amino acids. Cereal Chemistry. v. 30, n. 7, p. 1190-1206, 1958.

SPIES, J. R. Determination of tryptophan in proteins. Analytical Chemistry, v. 39, p. 1412-1415, 1967.

VIDOTTI, R.M. Produção e utilização de silagens de peixe na nutrição do pacu (Piaractus mesopotamicus), 2001. 65p. Tese (Doutorado) - Centro de Aquiicultura, Universidade Estadual Paulista "Júlio de Mesquita Filho", Jaboticabal, 2001.

VIDOTTI, R.M. et al. Amino acid composition of processed fish silage using different raw materials. Animal Feed 
Science and Technology. v. 105, n. 4. p. 199-204, 2003.

WANG, Y. et al. Effects of dietary carbohydrate level on growth and body composition of juvenile tilapia, Oreochromis niloticus x Oreochromis aureus. Aquaculture Research, v.36, n. 2, p.1408-1413, 2005. 